Jurnal SEMANTIKA

Volume 1, No. 1, Agustus 2019, p. 20-30

\title{
PENDAYAGUNAAN KONTEKS DALAM TINDAK TUTUR ANAK USIA 7 TAHUN DI MADRASAH DINIYAH TA'LIMUL HUDA DESA RANDUSANGA WETAN
}

\author{
Robert Rizki Yono \\ Prodi Pendidikan Bahasa dan Sastra Indonesia, Fakultas Keguruan dan Ilmu Pendidikan, \\ Universitas Muhadi Setiabudi Brebes, Indonesia \\ e-mail: Robertrizkiyono@umus.ac.id
}

\begin{abstract}
ABSTRAK
Seorang anak yang berusia tujuh tahun mempunyai kekhasan tersendiri dalam menggunakan bahasa. Seorang anak berkemungkinan mendayagunakan konteks untuk mendukung tuturannya. Hal ini dipengaruhi oleh cara berpikir anak. Pendayagunaan konteks dalam tindak tutur anak merupakan hal yang menarik untuk diteliti. Penelitian ini bertujuan untuk medeskripsikan pendayagunaan konteks dalam tindak tutur anak usia tujuh tahun di Madrasah Diniyah Ta'limul Huda Desa Randusanga Wetan. Penelitian ini menggunakan metode deskriptif kualitatif. Penelitian ini fokus pada pendayagunaan konteks dalam tindak tutur anak usia tujuh tahun di madrasah Randusanga Wetan. Berdasarkan hasil analisis data tentang pendayagunaan konteks pada anak usia tujuh tahun di Madrasah Diniyah Ta'limul Huda Desa Randusanga Wetan sebagai berikut. Pertama, Pendayagunaan konteks tempat untuk mendukung permohonannya dan menyatakan keberadaannya. Kedua, Pendayagunaan konteks waktu untuk menolak, meminta, dan mendukung keberhasilan menyatakan pendapatnya. Ketiga, Pendayagunaan konteks peristiwa untuk menyarankan dan meminta. Keempat, Pendayagunaan konteks suasana untuk mengajukan permintaannya kepada Pak Ustad Imam agar pulang lebih awal. Kelima, Pendayagunaan konteks orang Sekitar untuk mendukung permintaannya penutur agar dibelikan mainan dan mengancam.
\end{abstract}

Kata Kunci: Konteks, tindak tutur, anak

\begin{abstract}
A child who is seven years old has its own peculiarity in using language. A child is likely to use the context to support his speech. This is influenced by child thinking. The use of context in child speech act is an interesting things study. The purpose of ihis research is to describing the use of context in speech acts of seven-years-old in Madrasah Diniyah Ta'limul Huda in the village of Randusanga Wetan. This study used descriptive qualitative method. This study focuses on the use of context in speech acts of seven-years-old in Madrasah Diniyah Ta'limul Huda in the village of Randusanga Wetan. Based on the results of data analysis on context utilization in seven-years-old in Madrasah Diniyah Ta'limul Huda in the village of Randusanga Wetan as follows. First, the use of context place to support his request and state his existence. Second, the use of context time to reject, ask for, and support the success of the expression of his opinion. Third, the use of context events to give advice and ask for. Fourth, the use of context atmosphere to submit his request to Mr. Ustad Imam to go home early. Fifth, the use of context people around to support the request of speakers to buy toys and threaten.
\end{abstract}

Keywords: Context, speech act, child

Submitted: 2019, Accepted: 2019, Published: Agustus 2019

ISSN: Xxxx-Xxxx (online), Website: http://jurnal.umus.ac.id/index.php/semantika 
Jurnal SEMANTIKA, Volume 1, No. 1, Agustus 2019, p. 20-30

\section{PENDAHULUAN}

Bahasa adalah sistem komunikasi di antara anggota masyarakat yang menggunakan bunyi yang bekerja melalui alat ucap manusia, dan pendengaran, serta menggunakan lambang bunyi ujar yang memiliki makna konvensional yang arbitrer[1]. Bahasa juga mempunyai fungsi tersendiri sesuai dengan konteks yang berhubungan dengan suatu kejadian dan ekspresi.

Kemampuan berkomunikasi anak pada usia tujuh tahun akan terus meningkat karena semakin seringnya berinteraksi. Apalagi anak tersebut sudah bertambah kegiatan, diantaranya sekolah madrasah di waktu siang sampai sore, perkembangan bahasa yang dikuasai anak dipengaruhi oleh perkembangan usia anak dan lingkungan. Pada tahap preoperasional (2-7 tahun) anak mampu menggunakan bahasa dalam mengembangkan konsepnya walaupun seadanya[2].

Bahasa pertama atau dapat juga disebut dengan bahasa ibu. Hal ini sesuai dengan bahasa yang sering digunakan keluargannya (mayoritas dialek Brebes). Seorang anak berkemungkinan mendayagunakan konteks untuk mendukung tindak tuturnya. Peristiwa tutur Anak atau santri Madrasah terjadi di dalam kelas maupun di luar kelas dan waktu istirahat maupun kegiatan belajar mengajar di Madrasah.

Madrasah Diniyah Takmiliyah Awaliyah Ta'limul Huda Desa Randusanga Wetan adalah suatu lembaga pendidikan keagamaan Islam nonformal di bawah kementerian agama. Madrasah menyelenggarakan pendidikan agama islam tingkat dasar dengan masa belajar empat tahun dan jam belajarnya minimal 18 jam pelajaran dalam seminggu. Madrasah merupakan tempat belajar yang memberikan para siswa atau santri pengetahuan tentang agama dan akhlak yang mulia.

Tindak tutur dengan pendayagunaan konteks pada anak Madrasah sering kali berkomunikasi dengan teman sebaya, maupun dengan pendidik (Ustad), dengan memanfaatkan konteks. Pemanfataan konteks untuk mendukung keberhasilan tujuan tuturannya, inilah yang dimaksudkan dengan pendayagunaan konteks. Berdasarkan hasil observasi di Madrasah Diniyah Takmiliyah Awaliyah Ta'limul Huda Desa Randusanga Wetan dapat diketahui bahwa adakalanya anak dalam berkomunikasi memanfaatkan konteks.

Berdasarkan uraian di atas, dapat dikatakan bahwa aktivitas berkomunikasi anak merupakan topik yang menarik untuk dikaji. Hal ini didasari oleh kenyataan bahwa fenomena kebahasaan seperti yang dijelaskan di atas merupakan fenomena yang khas dimiliki anak-anak. Penelitian ini fokus pada pendayagunaan konteks dalam tindak tutur anak dalam tindak tutur anak usia tujuh tahun di Madrasah Diniyah Ta'limul Huda Desa Randusanga Wetan.

Penelitian ini dilakukan untuk mendeskripsikan pendayagunaan konteks dalam tindak tutur anak usia tujuh tahun di Madrasah Diniyah Ta'limul Huda Desa Randusanga Wetan.

Penelitian sebelumnya yang relevan dilakukan oleh [3] meneliti tentang pemahaman makna kontekstual dan sosial pada anak usia 4 sampai 8 tahun. Penelitian [4] juga meneliti tentang pengembangan pragmatik anak yang berkaitan dengan memahami orang lain secara efektif dalam berbagai konteks saat berkomunikasi. Penelitian [5] berkaitan dengan peran konteks situasi pada pemahaman anak tentang ucapan ekspresif. Selanjutnya, Damayanti (2018) dalam penelitiannya 
berkaitan dengan pendayagunaan Konteks dalam Tindak-tutur Guru Bahasa Indonesia pada Pembelajaran Debat di Kelas X.

\section{KAJIAN TEORI}

Kajian teori yang digunakan oleh peneliti, antara lain peristiwa tutur, tindak tutur, dan konteks.

Peristiwa tutur adalah serangkaian tindak tutur dalam bentuk ujaran yang melibatkan dua pihak, yaitu penutur dan lawan tutur dalam satu pokok tuturan, di dalam waktu, tempat, dan situasi tertentu[6]. Peristiwa tutur dapat berupa percakapan antara penjual dan pembeli (siswa Madrasah), peserta didik dengan pendidik, dan peserta didik dengan peserta didik.

Mengujarkan sebuah tuturan merupakan suatu tindakan yang dapat mempengaruhi atau memerintah lawan tuturnya. Pada dasarnya saat seseorang mengatakan sesuatu, dia juga melakukan sesuatu[7]. Dengan demikian, peristiwa tutur merupakan suatu hal yang selalu mucul bersamaan dengan tuturan.

Tiga jenis tindakan yang berkaitan dengan ujaran, yaitu lokusi, ilokusi, dan perlokusi.

(1)Lokusi, yaitu tindakan mengucapkan sesuatu sesuai makna yang diucapkan. Misal orang berkata "pusing" maka artinya pusing.

(2)Ilokusi, yaitu tindakan mengucapkan sesuatu yang berkaitan dengan maksud, fungsi, dan tindakan yang dimaksud. Misal kata "pusing" dapat diartikan pusing dan akan minum obat atau istirahat.

(3)Perlokusi, yaitu tindakan mengucapkan sesuatu yang menghasilkan efek dari ucapannya. Misal "pusing" maka ia berharap mitra tutur mengambilkan air beserta obat.

Secara realitas Searle membedakan jenis tindak tutur menjadi lima, yaitu representatif, direktif, ekspresif, komisif, dan deklarasi[6]:

(1)Representatif, yaitu tindak tutur yang mengikat penutur dengan kebenaran yang diucapkan. Misal menyatakan dan menunjukkan.

(2)Direktif, yaitu tindak tutur yang menghasilkan suatu efek berupa tindakan yang dilakukan penutur. Misal menyarankan dan memohon.

(3)Ekspresif, yaitu tindak tutur yang berfungsi untuk menyatakan sikap penutur terhadap suatu keadaan. Misalkan mengucapkan menyalahkan dan menyanjung.

(4)Komisif, yaitu tindak tutur yang mengikat penutur dimasa akan datang. Misalkan bersumpah dan mengancam.

(5)Deklarasi, yaitu tindak tutur yang berhubungan dengan isi tuturan dengan kenyataan. Misal mengabulkan dan mengizinkan.

Konteks merupakan pemerjelas suatu maksud. Konteks yang sering didayagunakan anak-anak untuk mendukung tuturannya ada lima konteks, yaitu (1) Konteks Tempat, (2) Konteks Waktu, (3) Konteks Peristiwa, (4) Konteks Suasana, dan (5) Konteks Orang Sekitar[8].

(1)Konteks Tempat.

Tempat yang melatari terjadinya peristiwa tutur pada saat anak bertutur. Konteks tempat yang didayagunakan oleh anak-anak diantaranya tempat disekitar anak saat bertutur yang berkaitan dengan tuturannya.

(2)Konteks Waktu.

Konteks waktu yang didayagunakan oleh anak-anak seperti waktu sekarang, dahulu, dan akan datang pada saat anak-anak bertutur.

(3)Konteks Peristiwa.

Peristiwa tutur yang terjadi ditentukan oleh peristiwa tertentu. 
Konteks peristiwa ini digunakan untuk mempengaruhi pendapat atau pandangan mitra tutur yang berhubungan dengan tuturannya.

(4)Konteks Suasana.

Suasana yang dimaksud adalah suasana-suasana yang sedih dan menyenangkan yang terjadi dalam peristiwa tutur.

(5)Konteks Orang Sekitar.

Konteks orang sekitar yang dimaksudkan berkaitan dengan orang-orang yang berada disekitar anak ataupun orang sekitar yang berada ditempat lain yang berkaitan dengan anak ketika menyampaikan tuturannya.

\section{METODE PENELITIAN}

Dalam bab ini dikemukanan (1) Pendekatan dan metode penelitian, (2) Objek penelitian, (3) Lokasi dan Waktu Penelitian, (4) Wujud dan sumber data, (5) Teknik Pengumpulan data, (6) Teknik analisis data, dan (7) Teknik penyajian hasil analisis data.

Pendekatan pragmatik yang digunakan dalam penelitian ini. Metode deskriptif kualitatif digunakan dalam penelitian ini. Deskriptif kualitatif menggunakan cara penafsiran yang berbentuk deskripsi yang berupa katakata tertulis. Hal ini bertujuan agar memperoleh berbagai macam pendayagunaan konteks dalam tindak tutur anak usia tujuh tahun di Madrasah Diniya Ta'limul Huda Desa Randusanga Wetan.

Objek penelitian ini tuturan siswa Madrasah Diniyah (anak usia 7 tahun) Desa Randusanga Wetan Kec/Kab. Brebes yang didalamnya terdapat pendayagunaan konteks.

Lokasi penelitian ini dilaksanakan di Madrasah Diniyah Takmiliyah Awaliyah Ta'limul Huda Desa Randusanga Wetan. Penelitian ini dilakukan pada bulan Mei-Juli 2019.
Wujud data dalam penelitian ini berupa percakapan lisan yang dilakukan oleh Anak-anak Madrasah yang berusia 7 tahun yang didalamnya terdapat tindak tutur dengan pendayagunaan konteks. Data tersebut diperoleh dari tuturantuturan yang dihasilkan oleh Anak-anak Madrasah dalam percakapan sehari-hari dengan mitra tuturnya, yakni pendidik atau ustad, teman-teman, dan orang lain yang sempat berkomunikasi dan menjadi sasaran komunikasinya. Percakapan sehari-hari yang dimaksud yaitu percakapan yang terjadi dalam peristiwa komunikasi alamiah di lingkungan Madrasah.

Sumber data penelitian ini terdapat dua sumber, yaitu sumber data primer dan sekunder. Data primer dalam penelitian ini adalah bahasa anak usia tujuh tahun di Madrasah Diniyah Takmiliyah Awaliyah Ta'limul Huda Desa Randusanga Wetan yang terdapat tuturan dengan pendayagunaan konteks. Data sekunder dalam penelitian ini adalah referensi tambahan dari internet, buku penunjang, dan penelitian yang relevan dengan objek penelitian.

Pada Penelitian ini digunakan teknik simak dan catat. Teknik simak yang digunakan adalah teknik simak bebas libat cakap. Teknik simak bebas libat cakap dilanjutkan dengan teknik catat. Tahap pengumpulan data yang pertama yaitu menyimak, dilanjutkan dengan mencatat dan mengklasifikasikan tuturan anak-anak Madrasah yang berusia tujuh tahun yang terdapat tindak tutur dengan pendayagunaan konteks. Catatan lapangan terdiri dari dua jenis yaitu catatan deskriptif dan reflektif. Lebih lanjut, bahwa teknik pengumpulan data dilakukan semata-mata untuk demi kepentingan analisis[9].

Teknik analisis data yang dilakukan menggunakan model interaktif yaitu, reduksi data, penyajian 
data, dan penarikan simpulan. Pertama, tahap reduksi data dengan cara mengklasifikasikan data yang diperoleh dilapangan berdasarkan fokus pada tuturan anak-anak Madrasah yang berusia tujuh tahun yang terdapat tindak tutur dengan pendayagunaan konteks. Kedua, tahap penyajian data dengan bentuk uraian singkat setelah dilakukan reduksi data. Ketiga, pada tahap terakhir ini melakukan penarikan kesimpulan yang didukung dengan bukti yang valid pada saat pengumpulan data[10].

\section{HASIL DAN PEMBAHASAN}

Konteks Tempat

Tempat yang melatari peristiwa tutur pada saat anak bertutur. Anak juga mendayagunakan konteks tempat untuk mendukung keberhasilan tuturannya. Seperti pada kutipan di bawah ini.

Data a

Konteks: Rehan berada lebih dekat dengan Sinta (pedagang di Madrasah) dibandingkan dengan Nesa. Padahal Nesa datang lebih awal.

Rehan S.: "Mbak Sinta, es marimase go aku ndisit."

Nesa : "Han, bisane kowen disit?" (ekspresinya kecewa)

Rehan S.: "Bonggane sapa, kowen ning kono." (sambil membawa es)

Nesa : "Dasare kowen njelei."

Sinta : "Ambelih Nes, kie lagi gawe go kowen."

Rehan S.: "hehehheheh" (tertawa dengan puasnya)

Peristiwa tutur pada data di atas, Rehan mendayagunakan konteks tempat. "Bonggane sapa, kowen ning kono". (sambil membawa es) merupakan sebuah upaya yang dilakukan anak dengan mendayagunakan konteks, keberadaan Rehan yang dekat dengan Sinta dimanfaatkan untuk mendukung tuturannya. Sehingga ia mendapatkan giliran lebih awal dibandingkan dengan Nesa. Padahal, Nesa datang lebih awal dibanding Rehan S. Yang seharusnya Nesa mendapatkan es lebih awal tetapi direbut oleh Rehan.

Data b

Konteks: Jihan sedang dijahili Rehan saat istirahat berlangsung

Jihan : "Wis gen, Han!" (ekspresil cemberut)

Rehan : "Ya ora." (sambil mengejarngejar)

Jihan : "Wis gen" (posisi di samping ruang ustad)

Rehan : "Iya" (sambil lari menjauh)

Peristiwa tutur di atas terjadi saat istirahat berlangsung. Rehan selalu mengejar-ngejar Jihan, sampai di samping ruang Ustad. Jihan mendayagunakan konteks tempat untuk mendukung tuturannya. Tuturan Jihan "Wis gen" (posisi di samping ruang ustad) merupakan sebuah upaya yang dilakukan Jihan untuk mendukung permohonannya kepada Rehan agar tidak menjailinya lagi. Rehanpun langsung lari menjauh agar perilakunya tidak ketahuan para ustad yang sedang istirahat di ruang kantor.

Data c

Konteks : Ketika bel masuk Riski masih bermain dan tidak masuk kelas, sampai ia bertemu dengan Ustad H. Hasan.

Ust. H. Hasan : "Mas Riski, bisane durung masuk ?"

Riski : "Ia Pak Ustad, kie pan maing wese." (sambil menutup pintu)

Ust. H. Hasan : "Eh" (sambil menuju kelas)

Pada data (c) merupakan pendayagunaan konteks tempat yang 
Jurnal SEMANTIKA, Volume 1, No. 1, Agustus 2019, p. 20-30

dilakukan Riski saat berkomunikasi dengan salah satu Ustad untuk mendukung tuturannya. Tuturan Riski "Ia Pak Ustad, kie pan maing wese." (sambil menutup pintu) merupakan tuturan untuk mendukung keberhasilan dengan tujuan agar Ustad tersebut percaya bahwa ia belum masuk karena akan ke WC. Padahal, ia hanya pura-pura supaya tidak masuk kelas karena masih bermain. Riski memanfaatkan dengan menyatakan keberadaannya di WC untuk mendukung tuturan.

\section{Konteks Waktu}

Waktu yang melatari peristiwa tutur pada saat anak bertutur. Konteks waktu yang didayagunakan anak diantaranya. Seperti kutipan di bawah ini.

Data d

Konteks: Kegiatan belajar mengajar kalini hafalan nadhoman.

Bu Ust. Nuti: "Rehan maju!"

Rehan S. : : "Aku Bu Ustad. Dongene Riski sing terlambat. (sambil kebingungan)"

Riski : "Akale mangkate ndisit aku."(sambil tersipu malu) Rehan Setiawan : "Ndisit aku." (agak marah)

Data (d) merupakan pendayagunaan konteks waktu yang digunakan Rehan untuk mendukung keberhasilan tuturannya untuk menolak permintaan dari Bu Ustad Nuti. Karena pada hari biasanya saat maju hafalan Nadhoman, $\mathrm{Bu}$ Nuti selalu menutamakan santri yang terlambat. "Aku Bu Ustad. Dongene Riski sing terlambat." (sambil kebingungan) merupakan tuturan yang digunakan dengan mendayagunakan waktu. Faktanya, Rehan datang lebih awal dibandingkan Riski. Riski takut maju duluan karena ia belum hafal.

Data e

Konteks: Bel Istirahat berbunyi namun $\mathrm{Bu}$ Ust. masih mencatat daftar tabungan santri

Putri : "Bu ustad. Aku tak istirahat disit ya, soale wis bel." (sambil tersenyum)

Bu Ust. Nuti : "IyaPut. $\mathrm{Bu}$ Ust. tanggung lagi ngetung duit tabungan."

Data (e) merupakan pendayagunaan konteks waktu yang digunakan Putri untuk mendukung keberhasilan tuturannya karena Putri mengatakan "Bu ustad. Aku tak istirahat disit ya, soale wis bel." (sambil tersenyum). Tuturan tersebut mendayagunakan konteks waktu sebab bel istirahat (waktu istirahat) sudah berbunyi namun $\mathrm{Bu}$ Nuti belum keluar dari kelas. Sehingga Putri berusaha memanfaatkan waktu sekarang yaitu waktu istirahat sudah tiba. Konteks waktu sekarang untuk memberikan pertimbangan kepada $\mathrm{Bu}$ Ust. untuk mengabulkan permintaan yang diajukan Putri.

Data $\mathrm{f}$

Konteks: Perkelahian antara Bryan dengan Zami.

Zami :"Lara kah.” (sambil menangis dan membalas dengan menendang)

Bryan : "Kowen ndisit kah." (agak marah)

Zami : "Aja takilan.” (marah)

Bryan : "Raimu." 
Jurnal SEMANTIKA, Volume 1, No. 1, Agustus 2019, p. 20-30

Pada data (f) merupakan pendayagunaan konteks waktu yang dilakukan Bryan saat berkomunikasi dengan Zami untuk mendukung keberhasilan menyatakan pendapatnya agar tidak disalahkan. Peristiwa tersebut terjadi ditonton banyak anak-anak lainnya. Selain itu, tuturan Bryan "Kowen ndisit kah." (agak marah) juga agar menggambarkan bahwa yang salah adalah Zami, dimata teman-temannya. Pada akhirnya keduan anak tersebut menangis.

\section{Konteks Peristiwa}

Peristiwa yang melatari peristiwa tutur ketika seorang anak bertutur. Peristiwa tutur yang terjadi ditentukan oleh sebuah peristiwa. Konteks peristiwa ini digunakan untuk mempengaruhi pendapat atau pandangan mitra tutur yang berhubungan dengan tindak tutur yang dilakukan. Konteks peristiwa ini didayagunakan anak untuk mendukung keberhasilan tuturannya yang berupa peristiwa tertentu yang istimewa ataupun merugikan anak dan berharap mendapatkan kompensasi. Seperti kutipan dibawah ini.

Data $g$

Konteks:Rehan mengomentari perkelahian yang telah terjadi antara Zami dengan Bryan

Rehan : "Mulane aja cengkereg." (agak marah)

Bryan :"Aku ora"(sambil menangis)

Rehan Syafi'i : "anjoge nangis, oh ya."

Peristiwa tutur yang terjadi pada data (g) merupakan sesuatu yang merugikan bagi anak yang berkelahi. Oleh karena itu, Rehan tidak menyianyiakan peristiwa ini untuk menyarankan jangan nakal, seperti pada tuturan "Mulane aja cengkereg." (agak marah. "Cengkereg" dalam bahasa Indonesia berati nakal. Peristiwa ini memberikan peluang bagi anak untuk tidak lagi berkelahi.

Data $h$

Konteks:Rehan mendatangi pedagang mainan yang bernama Eva menceritakan tentang mainan tadi yang baru dibeli.

Rehan S.: "Mba Eva, dolanane rusak."

Eva : "Aku ora ngerti, wis rusak ya gudu tanggung jawabe aku."

Rehan S.: "dijoli ya." (sambil menunjukan mainanya dengan ucapan yang lirih).

Peristiwa tutur di atas termasuk pendayagunaan konteks peristiwa merugikan bagi anak. Peristiwa merugikan tersebut Rehan tidak disia-siakannya untuk mendukung permintaannya. "dijoli ya." (sambil menunjukan mainanya dengan ucapan yang (irih). Rehan merasa bahwa Eva akan mengabulkan permintaanya karena mainan yang baru dibeli rusak. Dengan penuh keberanian anak berharap mendapatkan kompensasi dari si penjual mainan. Mengajukan permintaanya untuk menukar mainannya yang baru dibeli.

Konteks Suasana

Suasana yang melatari peristiwa tutur ketika seorang anak bertutur. Suasana yang dimaksudkan adalah suasana-suasana yang terjadi dalam peristiwa tutur. Anak mendayagunakan konteks seperti di bawah ini.

Data i

Konteks:Putri sedang berhasil
menghafalkan nadhoman
sebagai persyaratan pulang
karena pengajar tidak masuk
sehingga digantikan Ustad
Imam.

Putri : "Pak Ustad aku wis apal, tak balik ya!" (sambil tersenyum) 
Jurnal SEMANTIKA, Volume 1, No. 1, Agustus 2019, p. 20-30

Pak Ustad: "Iya, sing durung aja balik disit.

Data (i) merupakan pendayagunaan konteks suasana karena Putri melihat bahwa Ustad Imam merasa dalam suasana senang. Pak Imam senang karena melihat bahwa Putri berhasil menghafalkan nadhoman. Suasana tersebut dimanfaatkan untuk mengajukan permintaannya untuk pulang lebih awal. Pemanfaatan suasana ini lebih efektif dilakukan anak karena Imam memang telah berpesan kepada kelas 1 A agar sebelum pulang, santri harus menghafalkan Nadhoman terlebih dahulu.

\section{Konteks Orang Sekitar}

Konteks orang sekitar yang dimaksudkan berkaitan dengan orangorang yang berada disekitar anak baik secara langsung maupun tidak langsung yang berkaitan dengan ketika menyampaikan tuturannya. Seperti pada kutipan di bawah ini.

Data J

Konteks: Zami dan Riski sedang duduk santai di depan kelas. Zami ingin membeli cireng dan tibatiba Riski ingin membeli mainan yang tempatnya bersebelahan deng pedagang cireng.

Zami : "Tuku cireng ah."

Riski : "Zam, kowen pan tuku cireng?"

Zami : "Iya, aku pan tuku."

Riski : "Titip oh, tukukena mobilmobilan sing rongewu."
Data
(j) merupakan

pendayagunaan konteks orang sekitar yang dimanfaatkan Riski. Riski mendayagunakan Zami sebagai pihak yang berkepentingan. Selain itu, Riski mengakui bahwa ingin membeli mainan merupakan kepentingannya dan berharap bahwa Zami mengabulkan permintaannya.

Data k

Konteks:Percakapan antara Bilqis dengan Yasmin pada saat asyik bermain. Tiba-tiba Rehan datang dan menggagu mereka. Yasmin melihat kalau Ustad Sulton berada tidak jauh dari tempat mereka bermain.

Rehan : "Aku melu dolanan oh." (sambil tertawa)

Biqis :"Kowen senenge ganggu tok." (sambil kesal)

Rehan : "Melu be ora olih."

Yasmin :"Pak Ustad Sulton kie Rehan." (agak keras dan kesal)

Pada data (k) merupakan konteks orang sekitar yang dilakukan oleh yasmin dengan cara memanfaatkan keberadaan orang sekitar yaitu Pak Ustad diantara mereka bertiga untuk mengancam. Yasmin mendayagunakan keberadaan Pak Ustad di depan ruang Ustad yang letaknya dekat dengan tempat mereka bermain. "Pak Ustad Sulton kie Rehan." (agak keras dan kesal). Hal ini dilakukan agar Rehan Syafii menyadari bahwa suara Yasmin pasti terdengan Pak Ustad karena beliau tidak suka kalau ada santri madrasah yang nakal atau jail. Dengan cara tersebut Yasmin berharap agar Rehan tidak lagi mengganggu.

\section{Pembahasan}

Berdasarkan data dari hasil penelitian pendayagunaan konteks dalam tindak tutur anak usia tujuh tahun di Madrasah Diniyah Desa Randusanga Wetan sebagai berikut.

Pendayagunaan konteks Anak di Madrasah Diniyah Ta'limul Huda Desa randusanga Wetan didayagunakan dalam berkomunikasi antarsesama santri, santri dengan pedagang, dan santri dengan 
Ustad. Konteks yang didayagunakan oleh santri madrasah meliputi konteks tempat, waktu, peristiwa, suasana, dan orang sekitar untuk mendukung keberhasilannya dalam bertutur.

Pendayagunaan konteks tempat yang melatari anak bertutur untuk mendukung keberhasilan tuturannya yang dilakukan oleh Rehan Syafi'i, Jihan dan Riski. Seperti yang dilakukan Rehan syafi'i. Rehan mendayagunakan konteks tempat untuk mendapatkan giliran membeli es lebih awal dari Nesa, Jihan mendayagunakan konteks tempat untuk mendukung permohonannya kepada Rehan agar tidak menjailinya lagi,dan Riski mendayagunakan konteks untuk menyatakan keberadaannya.

Pendayagunaan konteks waktu yang melatari anak bertutur untuk mendukung keberhasilan tuturannya yang dilakukan oleh Rehan, Putri, dan Bryan. Seperti yang dilakukan Rehan Setyawan mendayagunakan konteks waktu untuk menolak permintaan dari $\mathrm{Bu}$ Ustad Nuti, Putri mendayagunakan konteks waktu untuk meminta istirahat kepada $\mathrm{Bu}$ Ustad Nuti, dan Bryan mendayagunakan konteks waktu untuk mendukung keberhasilan menyatakan pendapatnya.

Pendayagunaan konteks peristiwa yang melatari anak bertutur untuk mendukung keberhasilan tuturannya yang dilakukan oleh Rehan Syafi'i, dan Rehan Setyawan. Rehan Syafi'i mendayagunakan konteks peristiwa untuk menyarankan jangan nakal kepada Bryan, sedangkan Rehan Setyawan untuk meminta menukar mainannya yang rusak kepada eva dan berharap mendapatkan kompensasi.

Pendayagunaan konteks suasana yang melatari peristiwa tutur ketika seorang anak bertutur seperti yang dilakukan oleh Putri. Putri mendayagunakan konteks suasana untuk mengajukan permintaannya kepada Pak Ustad Imam agar pulang lebih awal.

Pendayagunaan konteks orang Sekitar yang melatari peristiwa tutur ketika seorang anak bertutur seperti yang dilakukan oleh Riski dan Yasmin. Riski mendayagunakan konteks orang sekitar untuk mendukung permintaannya penutur agar dibelikan mainan, sedangkan yasmin untuk mengancam Rehan Syafi'i agar tidak mengganggu.

\section{SIMPULAN}

Pendayagunaan konteks dalam tindak tutur anak usia tujuh tahun di Madrasah Diniyah Ta'limul Huda Desa randusanga Wetan didayagunakan dalam berkomunikasi antarsesama santri, santri dengan pedagang, dan santri dengan Ustad. Konteks yang didayagunakan oleh santri madrasah meliputi konteks tempat, waktu, peristiwa, suasana, dan orang sekitar untuk mendukung keberhasilannya dalam bertutur.

Pendayagunaan konteks dalam tindak tutur anak usia tujuh tahun di Madrasah Diniyah Ta'limul Huda Desa Randusanga Wetan didayagunakan untuk mendukung keberhasilan tuturannya dalam berkomunikasi. Pertama, Pendayagunaan konteks tempat untuk mendapatkan giliran membeli es lebih awal, mendukung permohonannya, dan menyatakan keberadaannya. Kedua, Pendayagunaan konteks waktu untuk menolak, meminta, dan mendukung keberhasilan menyatakan pendapatnya. Ketiga, Pendayagunaan konteks peristiwa untuk menyarankan dan meminta. Keempat, Pendayagunaan konteks suasana untuk mengajukan permintaannya kepada Pak Ustad Imam agar pulang lebih awal. Kelima, Pendayagunaan konteks orang Sekitar untuk mendukung permintaannya penutur agar dibelikan mainan dan mengancam. 
Saran penelitian ini sebagai berikut. Pertama, Pendayagunaan konteks dalam tindak tutur anak-anak perlu diteliti lebih lanjut, terutama pendayagunaan konteks suasana. Kedua, bagi para peneliti yang melakukan penelitian diharapkan meneliti tindak tutur anak sehingga memperoleh hasil yang bervariasi dan semakin banyak hasil penelitian terkait tindak tutur anak.

\section{REFERENCES}

[1] Subyantoro. 2014, Teori Pembelajaran Bahasa. Implementasi Psikolinguistik Pendidikan, Semarang, Unnes Press.

[2] Khasanah, N.N.,2012. Tindak Tutur Ekspresif dan Komisif di Kalangan Anak TK Berlatar Belakang Budaya Jawa Di Kecamatan Polanharjo Klaten, Naskah Publikasi, Program PBSID, Univ. UMS, Surakarta, [Online]. Available: https://www.google.com/url?sa=t $\underline{\text { \&source=web\&rct=j\&url=http://e }}$ prints.ums.ac.id/21046/18/02_NA SKAH_PUBLIKASI.pdf\&ved $=2 \mathrm{a}$ hUKEwj1, diakses tanggal 25 Juli 2019

[3] Loukusa, S., Makinen, L., Gabbatore, I., Nevala, P. L., dan Leinonen, E., 2017, De Gruyter Understanding Contektual and Social Meaning in Typically Developing Finnish-Speaking Four-to Eight-Year-Old Children. Journal Psychology of Language and Communication, vol. 21, no. 1, hal 408-428, [Online]. Available: http://iultika.oulu.fi/files/nbnfife201802083217.pdf diakses tanggal 10 Mei 2019.

[4] Cekalte, Asta., 2013, Child Pragmatic Development. The Encylopedia of Applied
Linguistics, Carol, A. (ed.):Blackwell Publishing Ltd, [Online]. Available: https://www.researchgate.net/publ ication/278322408_Child, diakses tanggal 10 Mei 2019.

[5] Aguert, M., Bigort, L., Laval, V., \& Bernicot, J., 2010, Understanding Expressive Speech Acts: The role of Prosody and Situational Context in FrenchSpeaking 5-to9-Years-olds, Journal of Speech, Language and Hearing Research,[Online] Available:https://scholar.google.c o.id/scholar?cluster $=17606583069$ 698303447\&hl=id\&as_sdt=2005 \&scoidt $=0,5$ diakses tanggal 10 Mei 2019.

[6] Ariyanti, L. D., \& Zulaeha, I., 2017, Tindak Tutur Ekspresif Humanis dalam Interaksi Pembelajaran di SMA Negeri 1 Batang: Analisis Wacana Kritis, Jurnal Seloka: Jurnal Pendidikan Bahasa dan Sastra Indonesia, vol. 6, no. 2, hal. 111-122.

[7] Martaulina, S. D., 2014, Fungsi Tindak Tutur Anak Usia Prasekolah dalam Ketrampilan Berbicara di Kelas Taman Kanakkanak, Majalah Ilmiah Politeknik Mandiri Bina Prestasi, vol. 3, no. 2, hal. 20-32, [Online]. Available: https://www.google.com/search?rl z=1C1GIGM enID834ID834\&ei =V6jbXPvkDo31rQH334q4DA\&q E+Fungsi+Tindak+Tutur+Anak+ Usia+Prasekolah+dalam+Ketramp ilan+Berbicara + di + Kelas + Taman + KanakKanak. +Jurnal+Majalah + Il miah+Politeknik+Mandiri+Bina $+\mathrm{P}$ restasi. $+3 \% 282 \% 29 \% 3$ A2032.\&oq =+Fungsi+Tindak+Tutur+Anak+ Usia+Prasekolah+dalam + Ketramp ilan+Berbicara + di + Kelas + Taman +KanakKanak.+Jurnal+Majalah+Il miah+Politeknik + Mandiri+Bina $+\mathrm{P}$ restasi. $+3 \% 282 \% 29 \% 3$ A2032.\&gs 
l=psyab.3...4622.4622..5776 ..0.0..0.

0.0......1...1...gws wiz.KJhvfisE5Tw, diakses tanggal 11 Mei 2019.

[8] Damayanti, R., 2018, Pendayagunaan Konteks dalam Tindak-tutur Guru Bahasa Indonesia pada Pembelajaran Debat di Kelas X Yayasan Pembina Unila Bandar Lampung Tahun Pelajaran 2017/2018, Skripsi, FKIP, Univ. Lampung, Bandar Lampung, [Online]. Available:

https://www.google.com/url?sa=t \&source=web\&rct=j\&url=http://d igilib.unila.ac.id/54668/3/SKRIPS I\%2520TANPA, diakses 7 Maret 2019.

[9] Sudaryanto, 2015, Metode dan Aneka Teknik Analisis Bahasa, Yogyakarta: Sananta Dharma University Press.

[10] Natalia, Melta, 2017, Agenda Setting Berita Pedofilia di Samarinda POS, eJournal Ilmu Komunikasi,No. 1, Vol.5, 283-297 [Online]. Available: http://ejournal.ilkom.fisipunmul.ac.id/site/wpcontent/uploads/2017/02/JURNA $\underline{\mathrm{L} \%}$ 